\title{
Synthesis, Characterization and Evaluation of the Anticancer and Antimicrobial Activities of Some Novel Benzazole and Benzazine Derivatives
}

\author{
Wesam. S.Shehab ${ }^{1,4^{*}}$, Naglaa. Z.H.Eleiwa ${ }^{2}$ and Samar.M.Mouneir ${ }^{3,4}$ \\ 1 Department of Chemistry, Faculty of Science, Zagazig University, Zagazig, Egypt \\ E-mail address: dr wesam123@yahoo.com
}

2 Department of Pharmacology, Faculty of Veterinary Medicine, Zagazig University, Zagazig, Egypt

E-mail address: nag_zakaria@yahoo.com

3 Department of Pharmacology, Faculty of Veterinary Medicine, Cairo University, Cairo, Egypt

E-mail address : samar_mouneir@yahoo.com

4 Faculty of Clinical Pharmacy, Taif University, Taif, KSA

\begin{abstract}
The present study was designed to synthesize and develop new useful lead compounds (some novel benzazole and benzazine derivatives ) of simple structure, exhibiting optimal in vitro anticancer and antimicrobial potency. Phenylenediamine derivative 1 was condensed with dithiocarboxylic acid derivatives 2 and produced benzimidazole derivative 4 . The benzotriazepines $\mathbf{8}$ and $\mathbf{1 0}$ were formed by the reaction of 1 with dicarbonyl derivatives followed by intermolecular coupling reaction. The synthesis of benzotriazine12, benzotriazole 14,17, benzimidazole16 and benzothiadiazine 19 from compound 1 was also described. The Synthesized Compounds were characterized by Spectral Studies like IR, $\mathrm{H}^{1}-\mathrm{NMR}$ and Analysis Spectra. The title compounds were screened for their possible In vitro anticancer and antimicrobial activities. Among the synthesized compounds, some have shown promisingly remarkable activities against different cancer cell lines (MCF-7 human breast cancer cells, HepG2 human hepatocarcinoma cells and PC3 human prostate cancer cells)and moderate to high antibacterial and antifungal activities. The obtained results showed that the most active compounds could be useful as a template for future design, modification and investigation to produce more active analogs.
\end{abstract}

\section{Keywords}

Diamine, benzotriazepine, benzotriazole, benzimidazole ,benzothiadiazine, anticancer and antimicrobial activities .

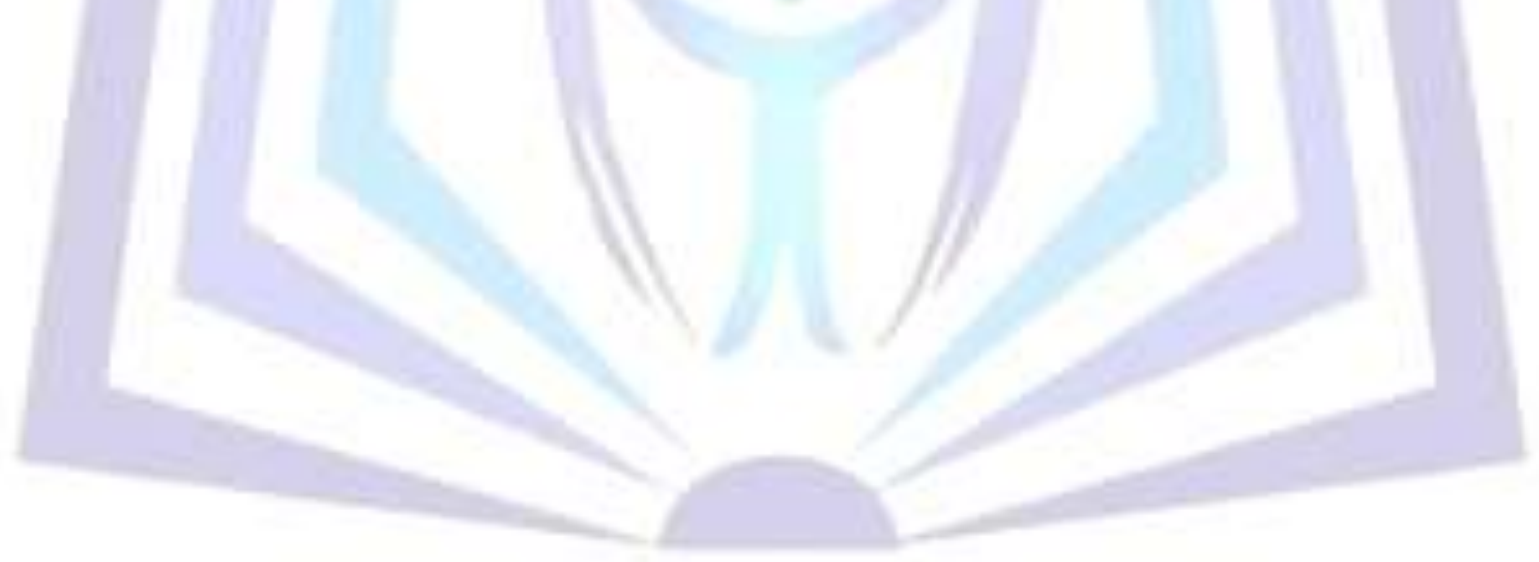

\section{Council for Innovative Research}

Peer Review Research Publishing System

Journal: Journal of Advances in Chemistry

Vol 3, No. 3

editor@cirworld.com

www.cirworld.com, member.cirworld.com 


\section{INTRODUCTION}

Cancer is a broad term used to encompass several malignant diseases. It defined as the uncontrolled and undifferentiated growth of abnormal cells that can affect every organ in the body and sometimes forming excess tissue known as tumor. It considered the second leading cause of death following cardiovascular diseases and it is one of the most dreadful disease despite the current improved methods of precautions, detections, surgery and therapy hence prevention of cancer is still the recognized goal of many activities in cancer research [1].

In addition, the incidence of fungal and bacterial infections has increased dramatically [2].The widespread use of antifungal and antibacterial drugs and their resistance against fungal and bacterial infections has led to serious health hazards. The resistance of wide spectrum antifungal and antibacterial agents has initiated discovery and modification of the new antifungal and antibacterial agents [3].

On the other hand, Benzazole derivatives were reported as very useful intermediates or subunits of the development of pharmaceutical or biological interest [4]. Their application were recorded in diverse therapeutic areas including anti-histaminic [5], anti-inflammatory [6], antiulcer [7], antihypertensive, antiviral, antifungal [8], and anticancer [9] activities. On the same ground, benzazine derivatives have attracted considerable interest in their biological activity [10] because they are used as antifungal, antimicrobial [11], anti-inflammatory [12] and anticancer agents [13, 14].

In view of the above observations, the current work was conducted to synthesize new compounds (some novel benzazole and benzazine derivatives ) of pharmacological interest and screen all the synthesized compounds for their possible in vitro anticancer and antimicrobial activities as an attempt to find out new biological active compounds in the line of anticancer and antimicrobial therapy.

\section{EXPERIMENTAL}

\subsection{Chemistry: General}

All melting points are uncorrected and were determined on Gallenkamp electric melting point apparatus. IR spectra (KBr discs) were recorded on a FT/IR-400 spectrophotometer (Perkin Elmer). ${ }^{1} \mathrm{H}-\mathrm{NMR}$ spectra were recorded on a Varian$300\left(\right.$ DMSO- $\left.d_{6}\right)$ solution. Chemical shifts were reported as $\delta$ values relative to tetramethylsilane (TMS) as internal reference. The Analyses were carried out at Micro Analytical Center, Cairo University.

\section{5-Nitro-N-phenyl-1H-benzo[d]imidazol-2-amine 4a}

A mixture of compound $1(0.01 \mathrm{~mol})$, and phenyldithiocarbamic acid $(0.01 \mathrm{~mol})$ in acetic acid $(30 \mathrm{ml})$ was heated under reflux for 8 hours. The reaction mixture was cooled, poured into crashed ice and the separated solid product was filtered off, dried and crystallized from toluene and gave compound 4 a. Yield: $80 \%$; yellow crystals; m.p. $230-232^{\circ} \mathrm{C}$. IR: $3562(\mathrm{NH}), 1515(\mathrm{C}=\mathrm{N}), 1593(\mathrm{C}=\mathrm{N}) \mathrm{cm}^{-1}$ and ${ }^{1} \mathrm{H}-\mathrm{NMR}\left(\mathrm{DMSO}-\mathrm{d}_{6}\right): 7.27-8.35(\mathrm{~m}, J=8.7 \mathrm{~Hz}, 8 \mathrm{H}, \mathrm{Ar}-\mathrm{H}), 12.39(\mathrm{~s}, 1 \mathrm{H}, \mathrm{NH})$, 13.2(s, $1 \mathrm{H}, \mathrm{NH}$ ). Anal.: $\mathrm{C}_{13} \mathrm{H}_{10} \mathrm{~N}_{4} \mathrm{O}_{2}$ (254.25); Calcd.: $\mathrm{C}, 61.41 ; \mathrm{H}, 3.96 ; \mathrm{N}, 22.04$; Found: $\mathrm{C}, 61.44 ; \mathrm{H}, 3.99 ; \mathrm{N}, 22.08$.

\section{2-(5-Nitro-1H-benzo[d]imidazol-2-yl)-1-phenylethanone}

A mixture of 4-nitro-1,2-phenylenediamine 1 (0.01 mol), and 3-oxo-3-phenyldithiopropionic acid (0.01 $\mathrm{mol})$ in acetic acid $(30 \mathrm{ml})$ was heated under reflux for 10 hours. The reaction mixture was cooled, poured into crashed ice and the separated solid product was filtered off, dried and crystallized from toluene and gave compound 4b. Yield: 70\%; yellow crystals; m.p. 236-238 ${ }^{\circ} \mathrm{C}$. IR: $3562(\mathrm{NH}), 2922$ (aliphatic $\mathrm{CH}$ ), 1664 (C=O), $1593(\mathrm{C}=\mathrm{N}) \mathrm{cm}^{-1}$ and ${ }^{1} \mathrm{H}-\mathrm{NMR}\left(\mathrm{DMSO}_{-} \mathrm{d}_{6}\right): 2.49\left(\mathrm{~s}, 2 \mathrm{H}, \mathrm{CH}_{2}\right), 7.6-8.35(\mathrm{~m}, \mathrm{~J}=8.7 \mathrm{~Hz}, 10 \mathrm{H}, \mathrm{Ar}-\mathrm{H}), 13(\mathrm{~s}, 1 \mathrm{H}$, $\mathrm{NH}$ ). Anal.: $\mathrm{C}_{15} \mathrm{H}_{11} \mathrm{~N}_{3} \mathrm{O}_{3}$ (281.27); Calcd.: C, 64.05; H, 3.94; N, 14.94; Found: $\mathrm{C}, 64.01 ; \mathrm{H}, 3.90 ; \mathrm{N}, 14.90$.

\section{4-[(2-Amino-5-nitrophenyl)amino|pent-3-en-2-one 5}

A mixture of compound $1(0.01 \mathrm{~mol})$ and acetylacetone $(0.01 \mathrm{~mol})$ in toluene $(60 \mathrm{ml})$ was heated under reflux for 4 hours. The solid product obtained upon cooling was filtered off, dried and crystallized from benzene and gave compound 5. Yield: $85 \%$; red crystals; m.p. $170-172{ }^{\circ} \mathrm{C}$. IR: 3436 and $3336\left(\mathrm{NH}_{2}\right), 1643(\mathrm{C}=\mathrm{O}), 1591(\mathrm{C}=\mathrm{N}) \mathrm{cm}^{-1}$ and ${ }^{1} \mathrm{H}-\mathrm{NMR}$ (DMSO-d $\left.\mathrm{d}_{6}\right): 2.49\left(\mathrm{~s}, 3 \mathrm{H}, \mathrm{CH}_{3}\right), 2.5\left(\mathrm{~s}, 3 \mathrm{H}, \mathrm{CH}_{3}\right), 5\left(\mathrm{~s}, 2 \mathrm{H}, \mathrm{NH}_{2}\right), \quad 6\left(\mathrm{~s}, 2 \mathrm{H}, \mathrm{CH}_{2}\right), 7.37-7.42(\mathrm{~m}, \mathrm{~J}=8.7 \mathrm{~Hz}, 3 \mathrm{H}, \mathrm{Ar}-\mathrm{H})$. Anal.: $\mathrm{C}_{11} \mathrm{H}_{13} \mathrm{~N}_{3} \mathrm{O}_{3}$ (235.24); Calcd.: C, 56.16; $\mathrm{H}, 5.57 ; \mathrm{N}, 17.86$; Found: C, 56.06; H, 5.52; N, 17.83 .

\section{1-(4-Methyl-7-nitro-5H-benzo[c]|1,2,5]triazepin-3-yl)ethanone}

A stirred cold solution of compound $5(0.01 \mathrm{~mol})$ in hydrochloric acid $(20 \mathrm{ml})$ was treated drop wise with a cold solution of $\mathrm{NaNO}_{2}(0.01 \mathrm{~mol})$ in water $(5 \mathrm{ml})$. The reaction mixture was further stirred for 1 hour, and the separated solid product was filtered off, washed with water, dried and crystallized from toluene and gave compound 7. Yield: 85\%; white crystals; m.p. $224-225^{\circ} \mathrm{C}$. IR: $1698(\mathrm{C}=\mathrm{O}), 1477(\mathrm{~N}=\mathrm{N}) \mathrm{cm}^{-1}$ and ${ }^{1} \mathrm{H}-\mathrm{NMR}$ (DMSO-d6): $2.48\left(\mathrm{~s}, 3 \mathrm{H}, \mathrm{CH}_{3}\right), 2.5\left(\mathrm{~s}, 3 \mathrm{H}, \mathrm{CH}_{3}\right)$, 8-8, 32(m, 3H, Ar-H), 8.96(s, $1 \mathrm{H}, \mathrm{NH})$. Anal.: $\mathrm{C}_{11} \mathrm{H}_{10} \mathrm{~N}_{4} \mathrm{O}_{3}$ (246.23); Calcd.: C, 53.66; $\mathrm{H}, 4.09$; N, 22.75; Found: C, 53.69; $\mathrm{H}, 4.06 ; \mathrm{N}, 22.78$.

\section{N-(2-Amino-5-nitrophenyl)-3-oxobutanamide}


A mixture of compound $1(0.01 \mathrm{~mol})$ and ethylacetoacetate $(0.01 \mathrm{~mol})$ in toluene $(60 \mathrm{ml})$ was heated under reflux for 4 hours. The solid product obtained upon cooling was filtered off, dried and crystallized from benzene and gave compound 8. Yield: 90\%; orange crystals; m.p. 160-162 ${ }^{\circ} \mathrm{C}$. IR: 3348-3436 $\left(\mathrm{NH}_{2}\right), 3197(\mathrm{NH}), 1685$ (ketonic $\left.\mathrm{C}=\mathrm{O}\right), 1643$ (amide $\mathrm{C}=\mathrm{O}$ ) $\mathrm{cm}^{-1}$ and ${ }^{1} \mathrm{H}-\mathrm{NMR}\left(\mathrm{DMSO}_{-} \mathrm{d}_{6}\right): 2.49\left(\mathrm{~s}, 3 \mathrm{H}, \mathrm{CH}_{3}\right), 5\left(\mathrm{~s}, 2 \mathrm{H}, \mathrm{NH}_{2}\right), 6\left(\mathrm{~s}, 2 \mathrm{H}, \mathrm{CH}_{2}\right), 7.3-8(\mathrm{~m}, \mathrm{~J}=3.9 \mathrm{~Hz}, 3 \mathrm{H}, \mathrm{Ar}-\mathrm{H})$, 10.7(s, $1 \mathrm{H}, \mathrm{NH})$. Anal.: $\mathrm{C}_{10} \mathrm{H}_{11} \mathrm{~N}_{3} \mathrm{O}_{4}$ (237.22); Calcd.: C, 50.63; H, 4.67; N, 17.71; Found: C, 50.60; H, 4.61; N, 17.74 .

\section{7-Nitro-3H-benzo[c][1,2,5|triazepin-4(5H)-one ${ }_{10}$}

A stirred cold solution of compound $8(0.01 \mathrm{~mol})$ in hydrochloric acid $(20 \mathrm{ml})$ was treated drop wise with a cold solution of $\mathrm{NaNO}_{2}(0.01 \mathrm{~mol})$ in water $(5 \mathrm{ml})$. The reaction mixture was further stirred for 1 hour, and the separated solid product was filtered off, washed with water, dried and crystallized from benzene and gave compound 10. Yield: 90\%; white crystals; m.p. $260-261{ }^{\circ} \mathrm{C}$. IR: $1790(\mathrm{C}=\mathrm{O}), 3474(\mathrm{NH}), 1481(\mathrm{~N}=\mathrm{N}) \mathrm{cm}^{-1}$ and ${ }^{1} \mathrm{H}-\mathrm{NMR}(\mathrm{DMSO}-\mathrm{d} 6): 2.5\left(\mathrm{~s}, 2 \mathrm{H}, \mathrm{CH}_{2}\right)$, 8-8.32(m, $J=10.1 \mathrm{~Hz}, 3 \mathrm{H}, \mathrm{Ar}-\mathrm{H}), 8.96(\mathrm{~s}, 1 \mathrm{H}, \mathrm{NH})$. Anal.: $\mathrm{C}_{8} \mathrm{H}_{6} \mathrm{~N}_{4} \mathrm{O}_{3}$ (206.16); Calcd.: $\mathrm{C}, 46.61 ; \mathrm{H}, 2.93 ; \mathrm{N}, 27.18$; Found: $\mathrm{C}, 46.56 \mathrm{H}, 2.88 ; \mathrm{N}, 27.23$.

\section{$\mathrm{N}^{1}$-Benzylidene-5-nitrobenzene-1,2-diamine 11}

A mixture of compound $1(0.01 \mathrm{~mol})$ and benzaldehyde $(0.01 \mathrm{~mol})$ in absolute ethanol $(30 \mathrm{ml})$ was heated under reflux for 4 hours. The solid product obtained upon cooling was filtered off, dried and crystallized from methanol and gave compound 11. Yield: $90 \%$; pale red crystals; m.p. 120-122 ${ }^{\circ} \mathrm{C}$. IR: 3326 and $3368\left(\mathrm{NH}_{2}\right), 1579(\mathrm{C}=\mathrm{N}) \mathrm{cm}^{-1}$ and ${ }^{1} \mathrm{H}-\mathrm{NMR}$ (DMSO-d6): 5 (s, 2H, NH 2$), 6(\mathrm{~s}, 1 \mathrm{H}, \mathrm{CH}=\mathrm{N}), 7.37-8.2(\mathrm{~m}, \mathrm{~J}=8.7 \mathrm{~Hz}, 3 \mathrm{H}, \mathrm{Ar}-\mathrm{H})$. Anal.: $\mathrm{C}_{13} \mathrm{H}_{11} \mathrm{~N}_{3} \mathrm{O}_{2}$ (241.25); Calcd.: C, 64.72; H, 4.60; N, 17.42; Found: C, 64.77; H, 4.55; N, 17.47.

\section{6-Nitro-3-phenylbenzo[e][1,2,4]triazine}

A stirred cold solution of compound $11(0.01 \mathrm{~mol})$ in hydrochloric acid $(20 \mathrm{ml})$ was treated drop wise with a cold solution of $\mathrm{NaNO}_{2}(0.01 \mathrm{~mol})$ in water $(5 \mathrm{ml})$. The reaction mixture was further stirred for 2 hours, and the separated solid product was filtered off, washed with water, dried and crystallized from water and gave compound 12. Yield: 90\%; white crystals; m.p. $210-212^{\circ} \mathrm{C}$. IR: $1527(\mathrm{C}=\mathrm{N}), 1488(\mathrm{~N}=\mathrm{N}) \mathrm{cm}^{-1}$ and ${ }^{1} \mathrm{H}-\mathrm{NMR}$ (DMSO-d6): 8-8.9(m, 8H, Ar-H). Anal.: $\mathrm{C}_{13} \mathrm{H}_{8} \mathrm{~N}_{4} \mathrm{O}_{2}$ (252.23); Calcd.: C, 61.90; H, 3.20; N, 22.21; Found: C, $61.85 \mathrm{H}, 3.25$; N, 22.26.

\section{5-Nitro- $\mathrm{N}^{1}$-(1-phenylethylidene)benzene-1,2-diamine 13}

A mixture of compound $1(0.01 \mathrm{~mol})$ and Acetophenone $(0.01 \mathrm{~mol})$ in absolute ethanol $(30 \mathrm{ml})$ was heated under reflux for 4 hours. The solid product obtained upon cooling was filtered off, dried and crystallized from methanol and gave compound 13. Yield: $90 \%$; red crystals; m.p. $240-242^{\circ} \mathrm{C}$. IR: 3379 and $3435\left(\mathrm{NH}_{2}\right), 1594(\mathrm{C}=\mathrm{N}) \mathrm{cm}^{-1}$ and ${ }^{1} \mathrm{H}-\mathrm{NMR}(\mathrm{DMSO}-$ d6): 2.49(s, 3H, $\left.\mathrm{CH}_{3}\right), 5\left(\mathrm{~s}, 2 \mathrm{H}, \mathrm{NH}_{2}\right), 6.5-7.4(\mathrm{~m}, 8 \mathrm{H}, \mathrm{Ar}-\mathrm{H})$. Anal.: $\mathrm{C}_{14} \mathrm{H}_{13} \mathrm{~N}_{3} \mathrm{O}_{2}$ (255.28); Calcd.: C, 65.87; H, 5.13; N, 16.46; Found: C, 65.82; H, 5.16; N, 16.43 .

\section{6-Nitro-1-(1-phenylvinyl)-1H-benzo[d][1,2,3]triazole ${ }_{14}$}

A stirred cold solution of compound $13(0.01 \mathrm{~mol})$ in hydrochloric acid $(20 \mathrm{ml})$ was treated drop wise with a cold solution of $\mathrm{NaNO}_{2}(0.01 \mathrm{~mol})$ in water $(5 \mathrm{ml})$. The reaction mixture was further stirred for 2 hours, and the separated solid product was filtered off, washed with water, dried and crystallized from water and gave compound 14. Yield: 90\%; white crystals; m.p. $210^{\circ} \mathrm{C}$. IR: 1593 (olefinic $\left.\mathrm{C}=\mathrm{C}\right), 1490(\mathrm{~N}=\mathrm{N}) \mathrm{cm}^{-1}$ and ${ }^{1} \mathrm{H}-\mathrm{NMR}$ (DMSO-d6): 2.5(s, 2H, $\left.\mathrm{CH}_{2}\right), 8-8.9(\mathrm{~m}, 8 \mathrm{H}, \mathrm{Ar}-$ H).Anal.: $\mathrm{C}_{14} \mathrm{H}_{10} \mathrm{~N}_{4} \mathrm{O}_{2}$ (266.26); Calcd.: C, 63.15; H, 3.79; N, 21.04; Found: C, 63.18; H, 3.72; N, 21.09.

\section{$\mathrm{N}-$-[(2-Amino-5-nitrophenyl)carbamothioyl|benzamide ${ }_{15}$}

A mixture of compound $1(0.01 \mathrm{~mol})$ and benzoyl isothiocyanate $(0.01 \mathrm{~mole})$ in dry acetone $(20 \mathrm{ml})$ was heated under reflux for 2 hours. The solid product obtained during heating was filtered off, dried and crystallized from methanol and gave compound 15. Yield: 95\%; greenish crystals; m.p. $222-224{ }^{\circ} \mathrm{C}$. IR: 3407 and $3318\left(\mathrm{NH}_{2}\right), 3217(\mathrm{NH}), 1668$ $(\mathrm{C}=\mathrm{O}), 1256(\mathrm{C}=\mathrm{S}) \mathrm{cm}^{-1}$ and ${ }^{1} \mathrm{H}-\mathrm{NMR}\left(\mathrm{DMSO}-\mathrm{d}_{6}\right): 6.5\left(\mathrm{~s}, 2 \mathrm{H}, \mathrm{NH}_{2}\right), 7.4-8(\mathrm{~m}, \mathrm{~J}=7.8 \mathrm{~Hz}, 8 \mathrm{H}, \mathrm{Ar}-\mathrm{H}), 8.38(\mathrm{~s}, 1 \mathrm{H}, \mathrm{NH})$, 13(s, $1 \mathrm{H}, \mathrm{NH}$ ).Anal.: $\mathrm{C}_{14} \mathrm{H}_{12} \mathrm{~N}_{4} \mathrm{O}_{3} \mathrm{~S}$ (316.34); Calcd.: C, 53.16; H, 3.82; N, 17.71; Found: C, 53.11; H, 3.87; N, 17.76.

\section{N-(2-(Cyanomethyl)-6-nitro-1H-benzo[d]imidazole-1- carbonothioyl)benzamide 16}

A mixture of compound $15(0.01 \mathrm{~mol})$ and ethyl cyanoacetate $(0.01 \mathrm{~mol})$ in dimethylformaamide $(10 \mathrm{ml})$ was heated under reflux for 8hours. The reaction mixture was cooled, poured into crashed ice. The separated solid product was filtered off, dried and crystallized from benzene and gave compound 16. Yield: $80 \%$; dark brown crystals; m.p. $260-262{ }^{\circ} \mathrm{C}$. IR: $3106(\mathrm{OH}), 2215(\mathrm{CN}), 1560(\mathrm{C}=\mathrm{N}), 1337(\mathrm{C}=\mathrm{S}) \mathrm{cm}^{-1}$ and ${ }^{\mathrm{HNMR}}\left(\mathrm{DMSO}-\mathrm{d}_{6}\right): 2.5\left(\mathrm{~s}, 2 \mathrm{H}, \mathrm{CH}_{2}\right), 7.2-8.3(\mathrm{~m}, 8 \mathrm{H}, \mathrm{Ar}-\mathrm{H})$, 12.99(OH). Anal.: $\mathrm{C}_{17} \mathrm{H}_{11} \mathrm{~N}_{5} \mathrm{O}_{3} \mathrm{~S}$ (365.37); Calcd.: C, 55.89; H, 3.03; N, 19.17; Found: C, 55.84; H, 3.08 N, 19.22 .

\section{N-(1-(2-(Methyleneamino)-5-nitrophenyl)hydrazinecarbonothioyl)- benzamide 17}


A stirred cold solution of compound $15(0.01 \mathrm{~mol})$ in hydrochloric acid $(20 \mathrm{ml})$ was treated drop wise with a cold solution of $\mathrm{NaNO}_{2}(0.01 \mathrm{~mol})$ in water $(5 \mathrm{ml})$. The reaction mixture was further stirred for 2 hours, and the reaction mixture was diluted with water and the product separated was filtered off, washed with water, dried and crystallized from ethanol and gave compound 17. Yield: 90\%; brown crystals; m.p. 173-175 ${ }^{\circ} \mathrm{C}$. IR: $3367(\mathrm{OH}), 1666(\mathrm{C}=\mathrm{O}), 1575(\mathrm{C}=\mathrm{N}), 1269$ $(\mathrm{C}=\mathrm{S}) \mathrm{cm}^{-1}$ and ${ }^{1} \mathrm{H}-\mathrm{NMR}$ (DMSO- $\left.\mathrm{d}_{6}\right): 7.4-7.8(\mathrm{~m}, 8 \mathrm{H}, \mathrm{Ar}-\mathrm{H}), 8.3(\mathrm{~s}, 1 \mathrm{H}, \mathrm{NH}), 8.9(\mathrm{~s}, 1 \mathrm{H}, \mathrm{OH})$. Anal.: $\mathrm{C}_{15} \mathrm{H}_{13} \mathrm{~N}_{5} \mathrm{O}_{3} \mathrm{~S}(343.37)$; Calcd.: C, 52.47; H, 3.82; N, 20.40; Found: C, 52.44; H, 3.85; N, 20.43.

\section{$\mathrm{N}$-|(2-(Benzylideneamino)-5-nitrophenyl)carbamothioyl|benzamide 18}

A mixture of compound $15(0.01 \mathrm{~mol})$, benzaldhyde and $(0.01 \mathrm{~mol})$ in presence of catalytic amount of dimethylamine in absolute ethanol $(30 \mathrm{ml})$ was heated under reflux for 3hours. The solid product obtained upon cooling was filtered off, dried and crystallized from the methanol and gave compound 18. Yield: 50\%; yellow crystals; m.p. $250-253^{\circ} \mathrm{C}$. IR: 3345 $(\mathrm{OH}), 1505(\mathrm{C}=\mathrm{N}), 1317(\mathrm{C}=\mathrm{S}) \mathrm{cm}^{-1}$ and ${ }^{1} \mathrm{H}-\mathrm{NMR}\left(\mathrm{DMSO}-\mathrm{d}_{6}\right): 6.4(\mathrm{~s}, 1 \mathrm{H}, \mathrm{CH}=\mathrm{N}), 7.1-7.8(\mathrm{~m}, 13 \mathrm{H}, \mathrm{Ar}-\mathrm{H}), 8(\mathrm{~s}, 1 \mathrm{H}, \mathrm{NH})$, 8.5(s, $1 \mathrm{H}, \mathrm{OH})$.Anal.: $\mathrm{C}_{21} \mathrm{H}_{16} \mathrm{~N}_{4} \mathrm{O}_{3} \mathrm{~S}$ (365.37); Calcd.: C, 62.36; H, 3.99; N, 13.85; Found: $\mathrm{C}, 62.31 ; \mathrm{H}, 3.94 ; \mathrm{N}, 13.80$.

\section{N-(6-Nitro-1H-benzo[c] [1,2,5]thiadiazin-3-yl)benzamide 19}

A mixture of compound $15(0.01 \mathrm{~mol})$, iodine $(0.01 \mathrm{~mol})$ in acetic acid $(20 \mathrm{ml})$ was heated under reflux for $4 \mathrm{hours}$ The solid product obtained upon cooling was filtered off, dried and crystallized from ethanol and gave compound 19. Yield: 80\%; pink crystals; m.p. $270-273^{\circ} \mathrm{C}$. IR: $3442(\mathrm{NH}), 1663(\mathrm{C}=\mathrm{O}), 1560(\mathrm{C}=\mathrm{N}) \mathrm{cm}^{-1}$. ${ }^{1} \mathrm{H}-\mathrm{NMR}\left(\mathrm{DMSO}-\mathrm{d}_{6}\right): 7.2-8.5(\mathrm{~m}, 8 \mathrm{H}, \mathrm{Ar}-$ $\mathrm{H}), 13(\mathrm{~s}, 1 \mathrm{H}, \mathrm{NH}), 13.17(\mathrm{~s}, 1 \mathrm{H}, \mathrm{NH})$. Anal.: $\mathrm{C}_{14} \mathrm{H}_{10} \mathrm{~N}_{4} \mathrm{O}_{3} \mathrm{~S}$ (314.32); Calcd.: C, 53.50; H, 3.21; N, 17.82; Found: C, 53.53; $\mathrm{H}$, $3.24 \mathrm{~N}, 17.79$.

\subsection{Anticancer activity evaluation (Cytotoxicity Assessment ) :}

\subsubsection{Cell culture:}

MCF-7 human breast cancer cells \& HepG2 human hepatocarcinoma cells and PC3 human prostate cancer cells were purchased from the Egyptian Holding Company for Biological Products \& Vaccines (VACSERA), Giza, Egypt, and then maintained in the tissue culture unit (Faculty of Pharmacy, Ain Shams University, Cairo, Egypt). The cells were grown in RPMI-1640 medium, supplemented with $10 \%$ heat inactivated FBS, 50 units $/ \mathrm{mL}$ of penicillin and $50 \mathrm{mg} / \mathrm{mL}$ of streptomycin and maintained at $37^{\circ}$ in a humidified atmosphere containing $5 \% \mathrm{CO} 2$. The cells were maintained as "monolayer culture" by serial subculturing. Cell culture reagents were obtained from Lonza (Basel, Switzerland).

\subsubsection{SRB cytotoxicity assay:}

Cytotoxicity was determined using SRB method as previously described by Skehan et al. [15]. Exponentially growing cells were collected using $0.25 \%$ Trypsin-EDTA and seeded in 96-well plates at 1000-2000 cells/well in RPMI1640 supplemented medium. After $24 \mathrm{~h}$, cells were incubated for $72 \mathrm{~h}$ with various concentrations of the tested compounds. Following $72 \mathrm{~h}$ treatment, the cells will be fixed with $10 \%$ trichloroacetic acid for $1 \mathrm{~h}$ at $4 \stackrel{\circ}{\circ} \mathrm{C}$. Wells were stained for $10 \mathrm{~min}$ at room temperature with $0.4 \%$ SRB (Sulphorhodamine B )dissolved in $1 \%$ acetic acid. The plates were air dried for $24 \mathrm{~h}$ and the dye was solubilized with Tris- $\mathrm{HCl}$ for $5 \mathrm{~min}$ on a shaker at $1600 \mathrm{rpm}$. The optical density (OD) of each well was measured spectrophotometrically at $564 \mathrm{~nm}$ with an ELISA microplate reader (ChroMate-4300, FL, USA). The $\mathrm{IC}_{50}$ values were calculated according to the equation for Boltzman sigmoidal concentration-response curve using the nonlinear regression fitting models (Graph Pad, Prism Version 5).

\subsection{Antimicrobial activity evaluation :}

Antimicrobial activity of the tested compounds was determined using a modified Kirby-Bauer disc diffusion method [16]. Briefly, $100 \mu \mathrm{l}$ of the test bacteria/fungi were grown in $10 \mathrm{ml}$ of fresh media until they reached a count of approximately $108 \mathrm{cell} / \mathrm{ml}$ for bacteria or $105 \mathrm{cells} / \mathrm{ml}$ for fungi [17]. $100 \mu \mathrm{l}$ of microbial suspension was spread onto agar plates corresponding to the broth in which they were maintained. Isolated colonies of each organism that might be playing a pathogenic role should be selected from primary agar plates and tested for susceptibility by disc diffusion method $[18,19]$.

Of the many media available, NCCLS recommends Mueller-Hinton agar due to: it results in good batch-to-batch reproducibility. Disc diffusion method for filamentous fungi tested by using approved standard method (M38-A) developed by the [20] for evaluating the susceptibilities of filamentous fungi to antifungal agents.Disc diffusion method for yeasts developed by using approved standard method (M44-P) by the [21].

Plates inoculated with filamentous fungi as Aspergillus flavus at $25^{\circ} \mathrm{C}$ for 48 hours; Gram (+) bacteria as Staphylococcus aureus, Bacillus subtilis; Gram (-) bacteria as Escherichia coli, Pseudomonas aeuroginosa they were incubated at $35-37^{\circ} \mathrm{C}$ for $24-48$ hours and yeast as Candida albicans incubated at $30^{\circ} \mathrm{C}$ for $24-48$ hours and, then the diameters of the inhibition zones were measured in millimeters [16].

Standard discs of Tetracycline (Antibacterial agent), Amphotericin B (Antifungal agent) served as positive controls for antimicrobial activity but filter discs impregnated with $10 \mu \mathrm{l}$ of solvent (distilled water, chloroform, DMSO) were used as a negative control.

The agar used is Meuller-Hinton agar that is rigorously tested for composition and $\mathrm{pH}$. Further the depth of the agar in the plate is a factor to be considered in the disc diffusion method. This method is well documented and standard 
zones of inhibition have been determined for susceptible and resistant values.Blank paper disks (Schleicher \& Schuell, Spain) with a diameter of $8.0 \mathrm{~mm}$ were impregnated $10 \mu$ of tested concentration of the stock solutions.

When a filter paper disc impregnated with a tested chemical is placed on agar the chemical will diffuse from the disc into the agar. This diffusion will place the chemical in the agar only around the disc. The solubility of the chemical and its molecular size will determine the size of the area of chemical infiltration around the disc. If an organism is placed on the agar it will not grow in the area around the disc if it is susceptible to the chemical. This area of no growth around the disc is known as a "Zone of inhibition" or" Clear zone".For the disc diffusion, the zone diameters were measured with slipping calipers of the National Committee for Clinical Laboratory Standards [18].

Agar-based methods such as Etest and disk diffusion can be good alternatives because they are simpler and faster than broth-based methods [22,23].

\section{RESULTS and Discussion}

\subsection{Chemistry}

O-phenylenediamine seemed of suitable located functionally for further heterocyclization giving benzazoles and benzazines, thus the fusion of imidazole to benzene ring was achieved by one pot procedure via refluxing 0 phenylenediamine derivative and dithiocarboxylic acid derivatives.

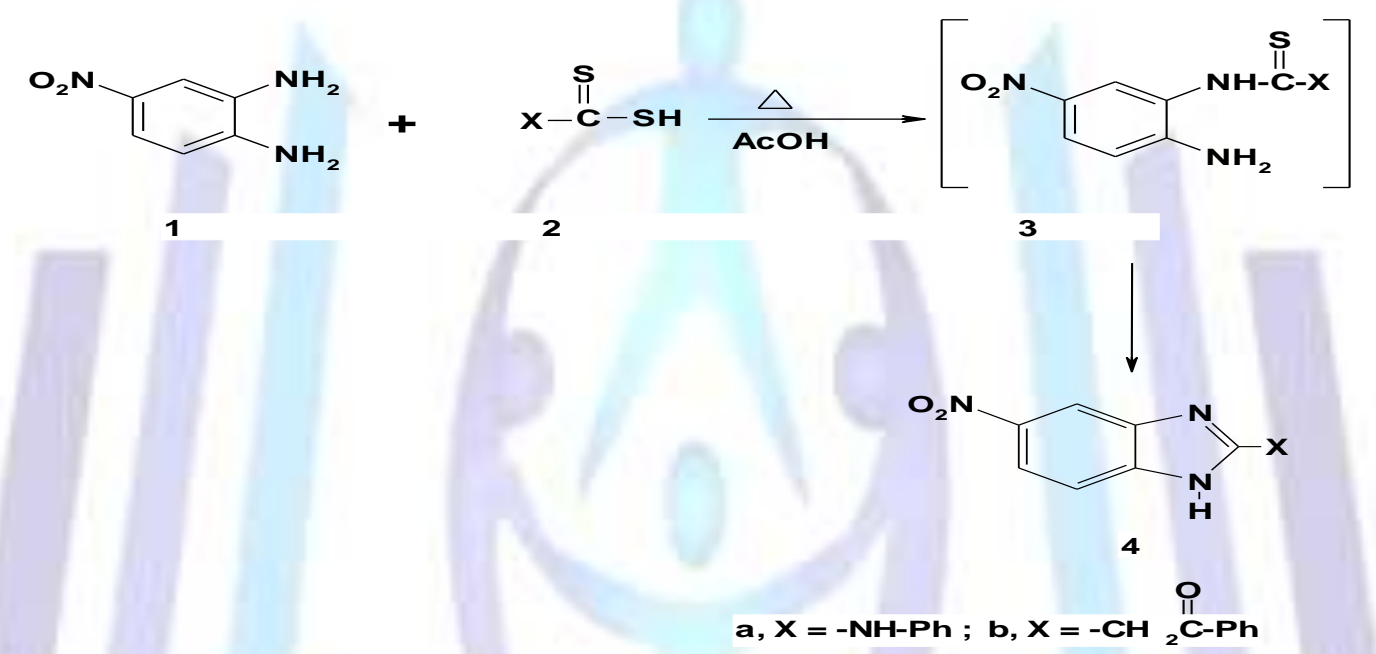

The reaction may be proceeded via the condensation reaction between the more basic amino group gave the nonisolable acyclic thioamide derivative followed by the intramolecular cyclocondensation via loosing $\mathrm{H}_{2} \mathrm{~S}$ and gave the final product 4. The IR spectrum of compound 4a showed absorption bands at $3562(\mathrm{NH}), 1515(\mathrm{C}=\mathrm{N}) \mathrm{cm}^{-1}$ and The ${ }^{1}$ HNMR spectrum of compound 4 a showed signals at $\delta 12.39 \mathrm{ppm}$ and $\delta 13.2 \mathrm{ppm}$ characteristic for $2 \mathrm{NH}$. The IR spectrum of compound $\mathbf{4 b}$ showed absorption bands at $3562(\mathrm{NH}), 1664(\mathrm{C}=\mathrm{O}) \mathrm{cm}^{-1}$ and The ${ }^{1} \mathrm{HNMR}$ spectrum of compound $\mathbf{4 b}$ showed signals at $\delta 2.49 \mathrm{ppm}$ characteristic for $\mathrm{CH}_{2}$ and at $\delta 13 \mathrm{ppm}$ characteristic for $\mathrm{NH}$.

The synthetic strategy toward the desired benzotriazepines depended on the condensation of o-phenylenediamine derivative 1 with dicarbonyl compound followed by diazotization and subsequent intramolecular coupling afforded the final benzazepine compounds. Thus condensation of compound $\mathbf{1}$ and acetylacetone gave the enaminic product 5 that undergo intramolecular heterocyclization via diazotization through the coupling of electrophilic nitrogen to the nucleophilic carbon 
and gave benzotriazepine 7 and none of the expected triazole 6 was obtained. (Scheme1)

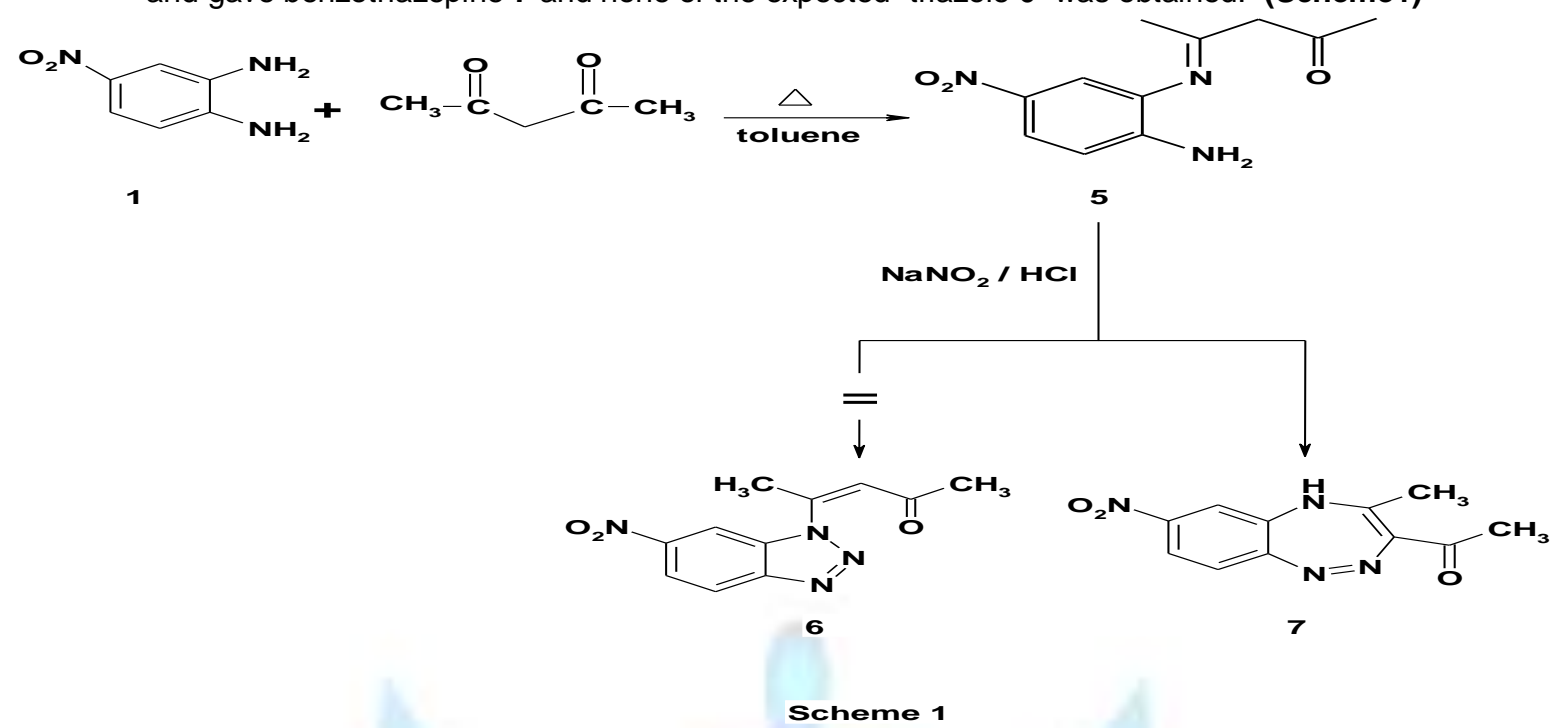

The formation of $\mathbf{7}$ is potentiated by the absence of enaminic proton in ${ }^{1} \mathrm{HNMR}$ spectrum.

The IR spectrum of compound 5 showed absorption bands at 3436 and $3336\left(\mathrm{NH}_{2}\right), 1643(\mathrm{C}=\mathrm{O}) \mathrm{cm}^{-1}$ and The ${ }^{1} \mathrm{H}-\mathrm{NMR}$ spectrum of compound 5 showed signals at $\delta 2.49$ and $2.5 \mathrm{ppm}$ characteristic for $2 \mathrm{CH}_{3}$ groups and at $\delta 6 \mathrm{ppm}$ characteristic for $\mathrm{CH}_{2}$. The IR spectrum of compound 7 showed absorption bands $1698(\mathrm{C}=\mathrm{O}) \mathrm{cm}^{-1}$ and The ${ }^{1} \mathrm{H}-\mathrm{NMR}$ spectrum of compound 7 showed signals at $\delta 2.48$ and $2.5 \mathrm{ppm}$ characteristic for $2 \mathrm{CH}_{3}$ groups and at $\delta 8.96$ ppm characteristic for $\mathrm{NH}$. Refluxing of phenylenediamine derivative 1 and ethyl acetoacetate resulted in the thermodynamic condensation product afforded acetoacetanilide derivative 8. Diazotization of compound $\mathbf{8}$ yielded benzotriazepine $\mathbf{1 0}$ presumably via the nonisolable benzotriazepine $\mathbf{9}$ that undergo spontaneous ketonic hydrolysis afforded compound $\mathbf{1 0}$. (Scheme 2)

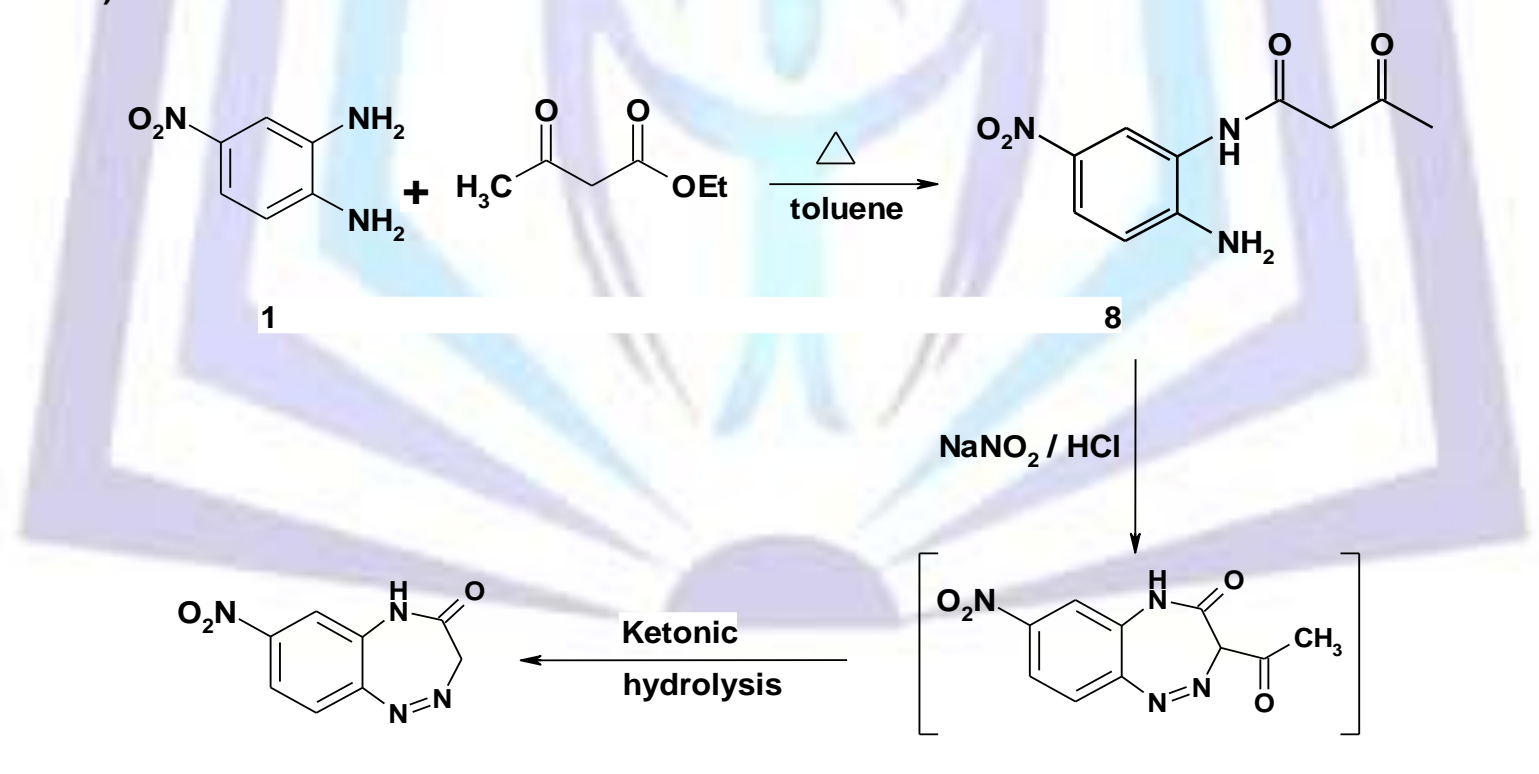

10

Scheme 2

The IR spectrum of compound 8 showed absorption bands at 1685 (ketonic $\mathrm{C}=\mathrm{O}$ ), 1643 (amide $\mathrm{C}=\mathrm{O}$ ) $\mathrm{cm}^{-1}$ and The ${ }^{1} \mathrm{HNMR}$ Spectrum of compound 8 showed signals at $\delta 2.49 \mathrm{ppm}$ characteristic for $\mathrm{CH}_{3}$ group and $\delta 6$ ppm characteristic for $\mathrm{CH}_{2}$. The IR spectrum of compound 10 showed absorption bands at $1790(\mathrm{C}=\mathrm{O}), 3474(\mathrm{NH}) \mathrm{cm}^{-1}$ and The ${ }^{1} \mathrm{HNMR}$ spectrum of compound 10 showed signals at $\delta 2.5 \mathrm{ppm}$ characteristic for characteristic for $\mathrm{CH}_{2}$.

Condensation of diamine derivative 1 and benzaldhyde afforded shiff base 11, That undergo intramolecular cyclization via reaction with nitrous acid produced benzotriazine 12. (Scheme 3) 
<smiles>Nc1ccc([N+](=O)[O-])cc1N</smiles>

1<smiles>Nc1ccc([N+](=O)[O-])cc1/N=C/c1ccccc1</smiles>

11<smiles>O=[N+]([O-])c1ccc2nnc(-c3ccccc3)nc2c1</smiles>

Scheme 3

12

The IR spectrum of compound 11 showed absorption bands at 3326 and $3368\left(\mathrm{NH}_{2}\right), 1579(\mathrm{C}=\mathrm{N}) \mathrm{cm}^{-1}$ and The ${ }^{1} \mathrm{HNMR}$ spectrum of compound 11 showed signals at $\delta 6 \mathrm{ppm}$ characteristic for $\mathrm{CH}=\mathrm{N}$. The IR spectrum of compound 12 showed absorption bands at $1527(\mathrm{C}=\mathrm{N}), 1488(\mathrm{~N}=\mathrm{N}) \mathrm{cm}^{-1}$ and The ${ }^{1} \mathrm{H}-\mathrm{NMR}$ spectrum of compound 12 showed signals at $\delta$ 8-8.9 ppm characteristic for $\mathrm{Ar}-\mathrm{H}$.

The amino compound 1 formed condensation product 13 with acetophenone. Compound 13 undergo intramolecular cyclization via reaction with nitrous acid gave benzotriazole as final product 14 according to scheme 4 .

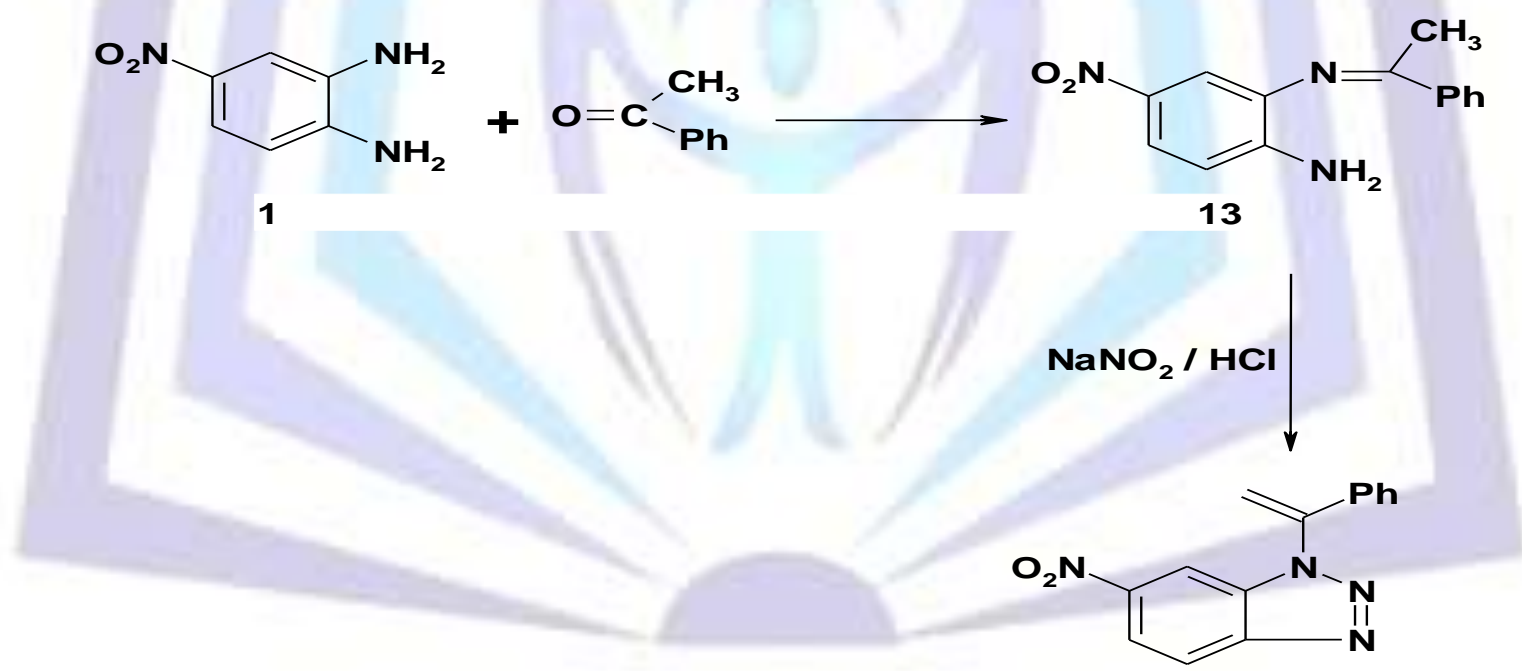

14

\section{Scheme 4}

The IR spectrum of compound 13 showed absorption bands at 3379 and $3435\left(\mathrm{NH}_{2}\right), 1594(\mathrm{C}=\mathrm{N}) \mathrm{cm}^{-1}$ and The ${ }^{1} \mathrm{HNMR}$ spectrum of compound 13 showed signal at $\delta 2.49 \mathrm{ppm}$ characteristic for $\mathrm{CH}_{3}$. The IR spectrum of compound 14 showed absorption bands at 1593 (olefinic $\mathrm{C}=\mathrm{C}), 1490(\mathrm{~N}=\mathrm{N}) \mathrm{cm}^{-1}$ and The ${ }^{1} \mathrm{H}-\mathrm{NMR}$ spectrum of compound 14 showed signal at $\delta 2.5 \mathrm{ppm}$ characteristic for $\mathrm{CH}_{2}$.

The amino compound $\mathbf{1}$ was added to the electrophilic carbon of isothiocyanate group of benzoylisothiocyanate produced thiourea derivative 15 . The IR spectrum of compound 15 showed absorption bands at $1668(C=O), 1256(C=S)$ $\mathrm{cm}^{-1}$ and The ${ }^{1} \mathrm{H}-\mathrm{NMR}$ spectrum of compound 15 showed signals at $\delta 8.38 \mathrm{ppm}$ and $\delta 13 \mathrm{ppm}$ characteristic for $2 \mathrm{NH}$ groups. Compound 15 undergo further heterocyclization and functionalization, thus when thiourea derivative 15 refluxed with ethylcyanoacetate produced benzimidazole derivative $\mathbf{1 6}$. The IR spectrum of compound $\mathbf{1 6}$ showed absorption 
bands at $3106(\mathrm{OH}), 2215(\mathrm{CN}), 1560(\mathrm{C}=\mathrm{N}) \mathrm{cm}^{-1}$ and The ${ }^{1} \mathrm{H}-\mathrm{NMR}$ spectrum of compound 16 showed signals at $\delta 2.5$ ppm characteristic for $\mathrm{CH}_{2}$ and $\delta 12.99$ ppm characteristic for $\mathrm{OH}$ group.

Diazotization of compound $\mathbf{1 5}$ afforded benzotriazole derivative 17. The IR spectrum of compound 17 showed absorption bands at $3367(\mathrm{OH}), 1666(\mathrm{C}=\mathrm{O}) \mathrm{cm}^{-1}$ and The ${ }^{1} \mathrm{H}-\mathrm{NMR}$ spectrum of compound 17 showed signals at $\delta$ 8.3ppm characteristic for $\mathrm{NH}$ and $\delta 8.9 \mathrm{ppm}$ characteristic for $\mathrm{OH}$.

Shiff base 18 was obtained via condensation of 15 with benzaldhyde. The IR spectrum of compound 18 showed absorption bands at $3345(\mathrm{OH}), 1505(\mathrm{C}=\mathrm{N}) \mathrm{cm}^{-1}$ and The ${ }^{1} \mathrm{H}$-NMR spectrum of compound 18 showed signal at $\delta 6.4$ ppm characteristic for $\mathrm{CH}=\mathrm{N}$ and $\delta 8.5 \mathrm{ppm}$ characteristic for $\mathrm{OH}$ group. (Scheme 5).

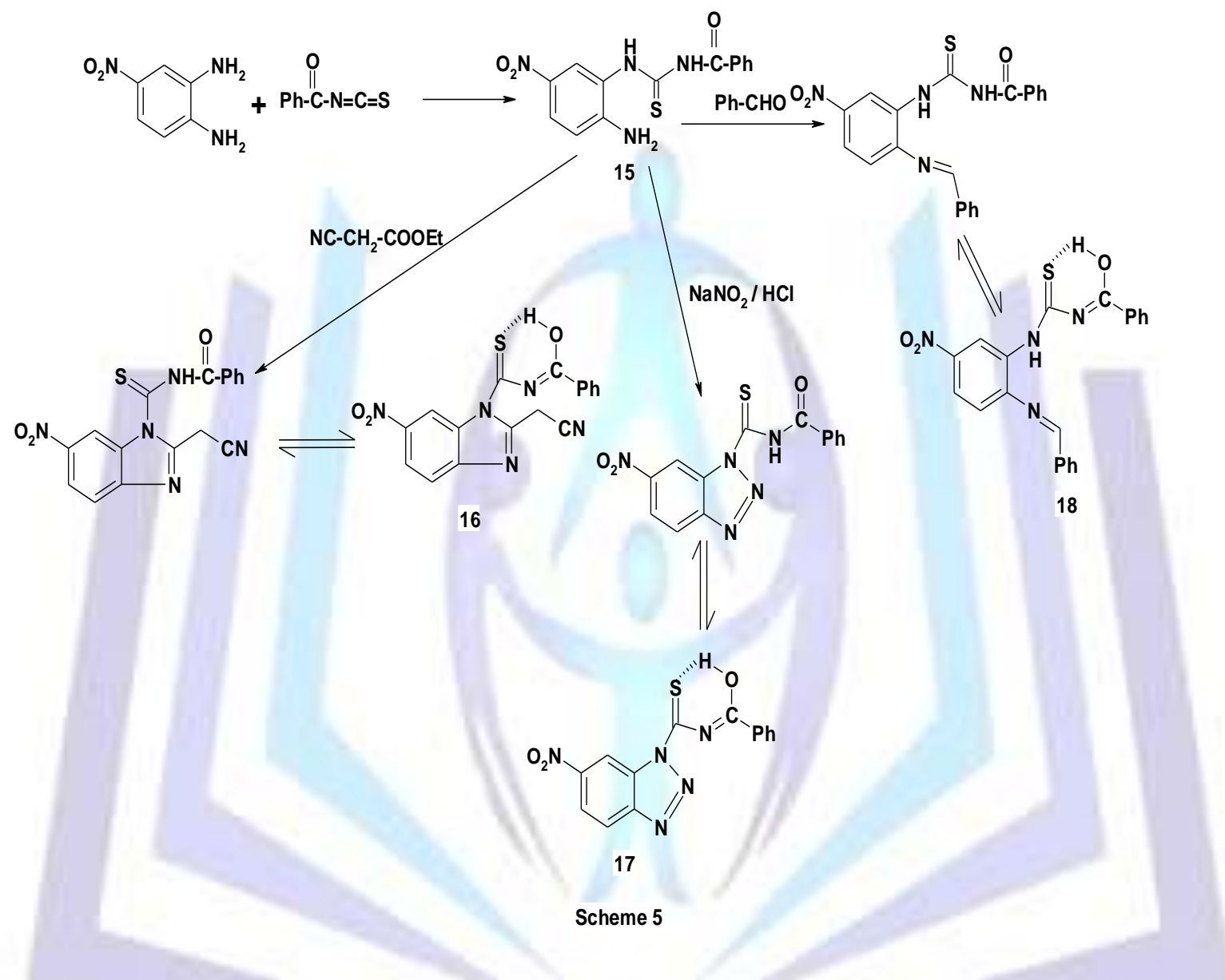

Oxidative cyclization of thiourea derivative 15 was achieved by refluxing compound 15 and iodine in acetic acid produced benzothiadiazine derivative 19 not the expected benzothiazole derivative 20 . The IR spectrum of compound 19 showed absorption bands $3442(\mathrm{NH}), 1663(\mathrm{C}=\mathrm{O}) \mathrm{cm}^{-1}$ and The ${ }^{1} \mathrm{H}-\mathrm{NMR}$ spectrum of compound 19 showed signals at $\delta$ $13 \mathrm{ppm}$ and $\delta 13.17 \mathrm{ppm}$ characteristic for $2 \mathrm{NH}$. (Scheme 6)

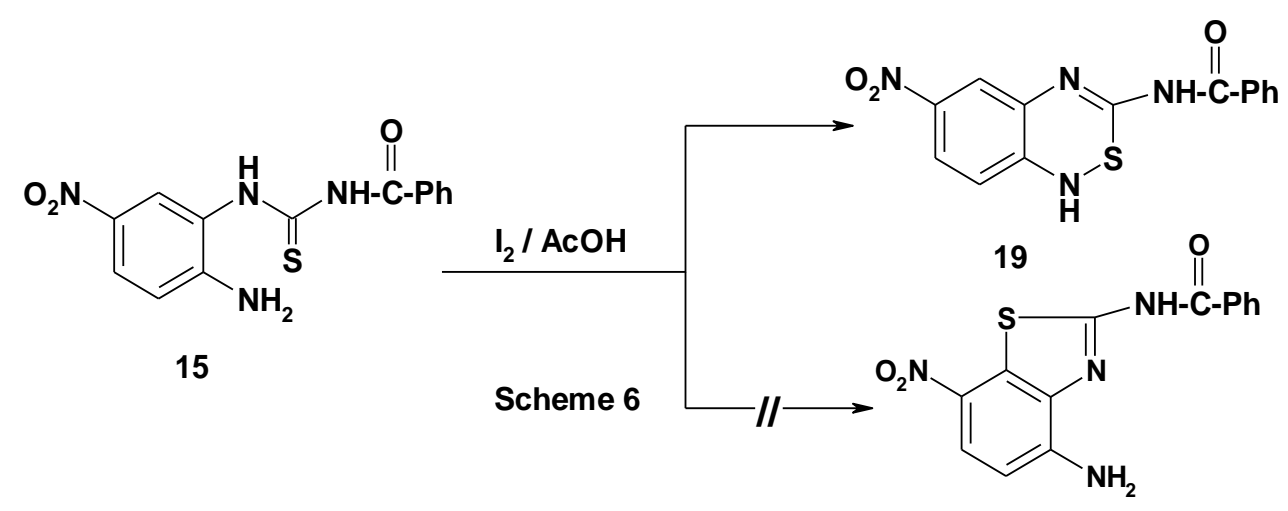




\subsection{Anticancer activity :}

All the synthesized compounds were tested for In vitro anticancer activity using SRB cytotoxicity assay method. The anticancer screening of the tested compounds revealed that, all the synthesized compounds exhibited non significant cytotoxic activity against MCF-7 human breast cancer cells \& Hep G2 human hepatocarcinoma cells and PC3 human prostate cancer cells lines except for compounds 19,16,14 which showed potent inhibitory effect on the examined cell lines ( Table 1 \& Figures 1,2,3).

From table (1), we can notice that compound 16 exhibited the most potent anticancer activity on MCF-7 human breast cancer cells by IC50 $(1.513 \mu \mathrm{M})$ while on Hep G2 human hepatocarcinoma cells and PC3 human prostate cancer cells compound 19 exhibited the maximum cytotoxic activity by IC50 (1.952 and $2.36 \mu \mathrm{M})$ respectively.

Table (1) : Anticancer activity of the target compounds against different cell lines

\begin{tabular}{|c|c|c|c|}
\hline \multirow{2}{*}{ Compound } & \multicolumn{3}{|c|}{ IC50 ( $\mu \mathrm{M})$} \\
\cline { 2 - 4 } & $\begin{array}{c}\text { MCF-7 human breast cancer } \\
\text { cells }\end{array}$ & $\begin{array}{c}\text { Hep G2 human hepatocarcinoma } \\
\text { cells }\end{array}$ & $\begin{array}{c}\text { PC3 human prostate cancer } \\
\text { cells }\end{array}$ \\
\hline 19 & 3.539 & 1.952 & 2.36 \\
\hline 16 & 1.513 & 2.405 & 3.657 \\
\hline 14 & 75.36 & 113.3 & 398.0 \\
\hline
\end{tabular}

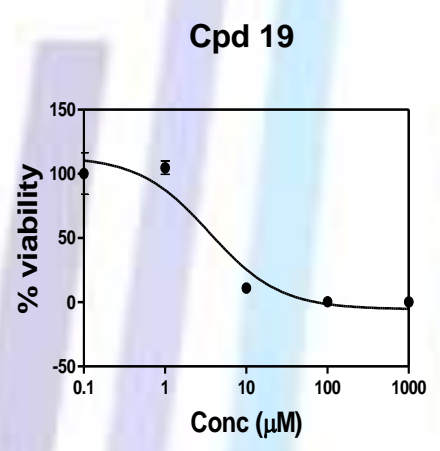

IC50 $=3.539 \mu \mathrm{M}$

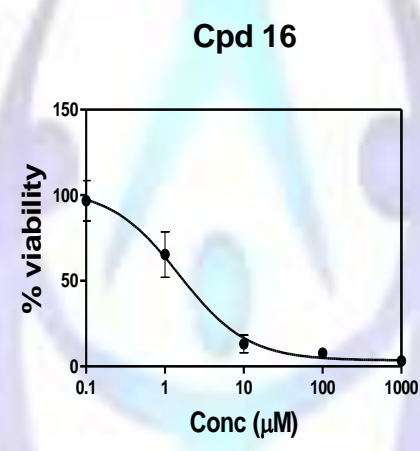

$I_{50}=1.513 \mu \mathrm{M}$

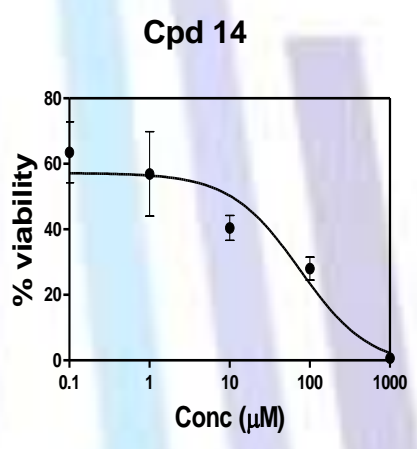

$I_{50}=75.36 \mu \mathrm{M}$

Fig.1 : Anticancer activity of the target compounds against MCF-7 human breast cancer cells

Cpd 19

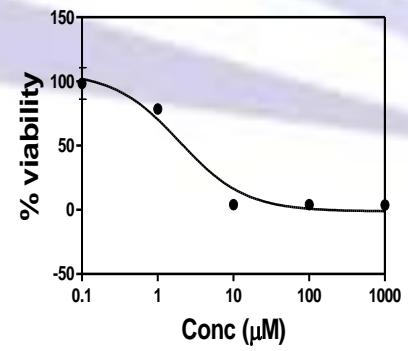

$I_{50}=1.952 \mu \mathrm{M}$
Cpd 16

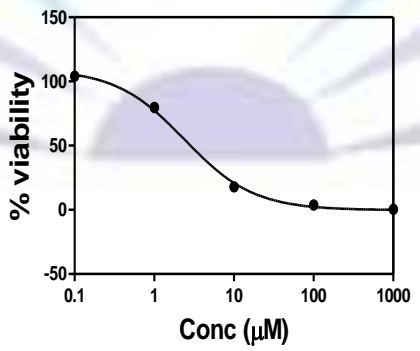

$\mathrm{IC}_{50}=2.405 \mu \mathrm{M}$
Cpd 14

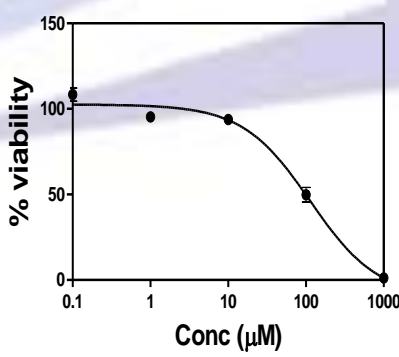

$\mathrm{IC}_{50}=113.3 \mu \mathrm{M}$

Fig.2 : Anticancer activity of the target compounds against Hep G2 human hepatocarcinoma cells Cpd 19 


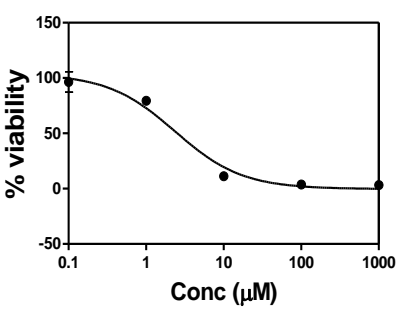

$\mathrm{IC}_{50}=2.36 \mu \mathrm{M}$

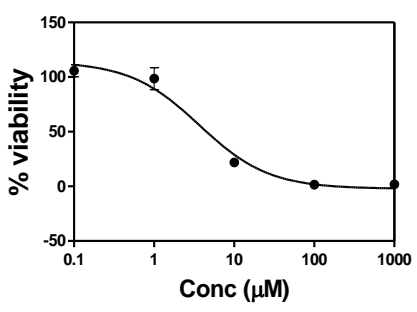

$\mathrm{IC}_{50}=3.657 \mu \mathrm{M}$

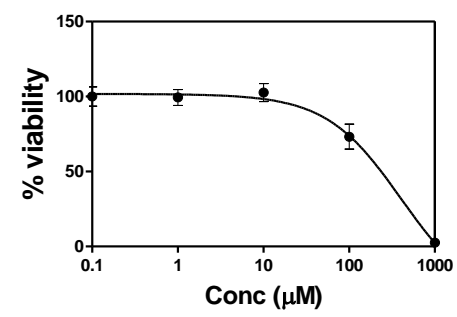

$\mathrm{IC}_{50}=398.0 \mu \mathrm{M}$

Fig.3 : Anticancer activity of the target compounds against PC3 human prostate cancer cells

\subsection{Antimicrobial activity :}

Antimicrobial activity of the tested compounds was examined using a modified Kirby-Bauer disc diffusion method and the inhibition zones caused by the various compounds on the microorganisms were determined. The results of the Antibacterial assay of all the titled compounds showed good activities against both Gram positive and Gram negative bacterial models. These activities were ranged from moderate to high and the most potent activities were belonged to compounds $\mathbf{1 4}$ and $\mathbf{5}$ compared with the activity of the standard antibacterial drug (tetracycline). The activity data generated are tabulated in Table 2.

From the data obtained in Table 2, it is also clear that all the tested compounds were found to be inactive against Aspergillus flavus while they exhibited moderate activity against Candida albicans compared with that of the standard antifungal drug (Amphotericin B) and the best results was belonged to compound 19.

Table 2. Antimicrobial activity of the tested compounds

\begin{tabular}{|c|c|c|c|c|c|c|c|}
\hline & Sample & $\begin{array}{c}\text { Bacillus } \\
\text { subtilis } \\
\left(\mathrm{G}^{+}\right)\end{array}$ & $\begin{array}{c}\text { Staphylococcus } \\
\text { aureus } \\
\left(\mathrm{G}^{+}\right)\end{array}$ & $\begin{array}{r}\text { Escherichia } \\
\text { coli } \\
(G)\end{array}$ & $\begin{array}{c}\text { Pseudomonas } \\
\text { aeruginosa } \\
\text { (G) }\end{array}$ & $\begin{array}{r}\text { Aspergillus } \\
\text { flavus } \\
\text { (Fungus) }\end{array}$ & $\begin{array}{r}\text { Candida } \\
\text { albicans } \\
\text { (Yeast) }\end{array}$ \\
\hline$\frac{0}{\pi}$ & $\begin{array}{l}\text { Tetracycline } \\
\text { Antibacterial } \\
\text { agent }\end{array}$ & 30 & 28 & 31 & 30 & -- & -- \\
\hline$\frac{\vec{T}}{\omega}$ & $\begin{array}{l}\text { Amphotericin B } \\
\text { Antifungal } \\
\text { agent }\end{array}$ & -- & -- & - & -- & 17 & 19 \\
\hline & ntrol: DMSO & 0.0 & 0.0 & 0.0 & 0.0 & 0.0 & 0.0 \\
\hline & $4 b$ & 9 & 11 & 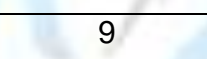 & 10 & 0.0 & 9 \\
\hline & 17 & 13 & 15 & 13 & 15 & 0.0 & 10 \\
\hline & 19 & 9 & 13 & 9 & 9 & 0.0 & 11 \\
\hline & $4 a$ & 10 & 14 & 11 & 11 & 0.0 & 9 \\
\hline & 16 & 10 & 9 & 11 & 11 & 0.0 & 9 \\
\hline & 14 & 25 & 27 & 25 & 27 & 0.0 & 9 \\
\hline & 5 & 21 & 24 & 25 & 25 & 0.0 & 10 \\
\hline & 7 & 13 & 10 & 15 & 15 & 0.0 & 0.0 \\
\hline & 10 & 18 & 22 & 20 & 13 & 0.0 & 0.0 \\
\hline
\end{tabular}

Note: '-'denotes no activity, 6-8 $\mathrm{mm}$ poor activity, 9-11 mm moderate activity, > $12 \mathrm{~mm}$ potent activity.

In the frame of our results, it is true and fitting to mention that earlier studies supported our findings . [24] reported that, some novel benzothiadiazine drevatives showed significant growth inhibitory activity against selected human tumor cell lines. Interestinlgy, one of the synthesized benzothiadiazine drevatives, exhibited GI50 values of 1.4 and $2.1 \mu \mathrm{M}$ against RPMI-8226 (leukemia) and HOP-62 (lungs) cell lines, respectively. The sulfamido moiety in the main heterocycle is crucial for cytotoxicity [25].In addition, it is documented previously that some modified benzothiadiazine drevatives exhibited remarkable potent inhibitory activity against many bacterial species in comparison to the standard drugs [26]. 
In keeping with this line, Benzimidazoles were reported to posses anticancer activity. They are potent anti-tumor, and anti-parasitic agents, whose mode of action is thought to result from their inhibition of microtubule ; the elements of spindle ; formation and functions that results in antimitotic effect [27].

Similarly, It was proved that , benzotriazole drevatives posses various biological activities including antimicrobial ad anticancer activities [28] and it has in vitro cytotoxic activity against human cancer cell lines including lung carcinoma (A549), cervix epithelial carcinoma (HeLa), osteosarcoma (HOS), malignant melanoma (G361), breast adenocarcinoma (MCF7), ovarian carcinoma (A2780) and cisplatin-resistant ovarian carcinoma (A2780cis) [29].

\section{CONCLUSION}

From the obtained results we can conclude that, benzothiadiazine derevative ( cpd 19) \& benzimidazole drevative ( cpd 16 ) and benzotriazole ( cpd 14) elicited the most potent cytotoxic effect on the tested cancer cell lines while, cpds 14 and 5 were the most active cpds against both gram +ve and gram-ve bacterial infection however cpd 19 was the best against fungal infection. These compounds could therefore serve as a lead promising molecules for further modification to obtain clinically useful anticancer and antibacterial agents.

In general ,The present study throws light on the identification of this new structural class as anticancer and antimicrobial agents which can be of interest for further detailed preclinical investigations

\section{REFERENCES}

[1] Bhushan,M.Panchabudhe. 2012. Synthesis ,characterization and invitro anticancer screening of thiazolidin -4-ones . IJPRD,vol.4: 295-300.

[2] Peara, S., Patterson, T.F.2002. Antifungal resistance in pathogenic fungi. Clin. Infect. Dis. 35, 1073-1080.

[3] Biot, C., Francois, N., Maciejewski, L., Brocard, J., Poulin, D.2000.Synthesis and antifungal activity of a ferrocenefluconazole analogue.Bioorg. Med. Chem. Lett. 10, 839-841.

[4] Narasimhan, B. ; Sharma, D. and Kumar, D. 2012. Benzimidazole: a medicinally important heterocyclic moiety. Med Chem Res 21:269-283.

[5] Goud, V.M.; Sreenivasulu, N.; Rao, AS. and Chigiri, S. 2011.Synthesis, antimicrobial and pharmacological evaluation of substituted novel benzimidazoles. Der Pharma Chemica 3:446-452.

[6] Samudrala, M.; Thallada, L.; Thallada, PK. and Veerati, PC. 2011. Synthesis and anti-inflammatory activity of 2-[(1Hbenzimidazole-2ylmethyl)sulfonyl]-n-(phenyl methylidine) acetohydrazide derivatives. Int J Res Pharm Chem 1:148-155.

[7] Patil, A.; Ganguly, S. and Surana, S. 2010.Synthesis and antiulcer activity of 2-[5-substituted-1-H benzo(d)imidazol-2ylsulfinyl]methyl-3-substituted quinazoline-4-(3H)ones. J Chem Sci 122:443-450.

[8] El-masry, AH.; Fahmy, HH. and Ali Abdelwahed, SH. 2000. Synthesis and antimicrobial activity of some new benzimidazole derivatives. Molecules 5:1429-1438.

[9] Kumar, D.; Jacob, MR.; Reynolds, MB. and Kerwin, SM. 2002. Synthesis and evaluation of anticancer benzoxazoles and benzimidazoles related to UK-1. Bioorg Med Chem 10:3997-4004.

[10] Salimon, J.and Salih, N. 2010. Synthesis, characterization and biological activity of some new1,2,4-triazine derivatives. Int. J. Pharm. Tech. Res., 2, 1041-1045.

[11] Marzena, M. Ucherek ; Joanna, wroblewska; Bozena, M. Banachiewicz and Eugenia, gospodarek. 2008. Biological activity of methyl 2-[5-oxo-3,4-di-(2-pirydyl)-1,4,5,6-tetrahydro-1,2,4-triazine-6-ylidene] acetate. Acta polo. Pharma.Drug Res., Vol. 65 No. 6 pp. 789-791.

[12] Mullick, P.; Khan, S.A.; Begum, T.; Verma, S.; Kaushik, D. and Alam, O. 2009. Synthesis of 1,2,4-triazine derivatives as potential anti-anxiety and anti-inflammatory agents. Acta Pol. Pharm. Drug Res. 66, 379-385.

[13] El-Gendy, Z.; Morsy, J.M.; Allimony, H.A.; Abdel-Monem, W.R.and Abdel-Rahman, R.M. 2001. Synthesis of heterobicyclic nitrogen systems bearing the 1,2,4-triazine moiety as anti-HIV and anticancer drugs. Part III. Pharmazie, 56, 376-383.

[14] Hosam, A. Saad; Mohamed, M. Youssef and Mosselhi, A. Mosselhi.2011.Microwave assisted synthesis of some new fused 1,2,4-triazines bearing thiophene moieties with expected pharmacological activity. Molecules, 16, 4937-4957.

[15] Skehan, P.; Storeng, R.; Scudiero, D.; Monks, A.; McMahon,J.;Vistica,D.; Warren, J.T. ; Bokesch, H. ; Kenney, S.and Boyd, M.R. 1990. New colorimetric cytotoxicity assay for anticancer-drug screening. J Natl Cancer Inst. 82:1107-1112

[16] Bauer, A.W, Kirby, W.M, Sherris, C., Turck, M.1966. Antibiotic susceptibility testing by a standardized single disk method, American Journal of Clinical Pathology, 45, 493-496.

[17] Pfaller, M. A., L. Burmeister, M. A. Bartlett, and M. G. Rinaldi. 1988. Multicenter evaluation of four methods of yeast inoculum preparation. J. Clin. Microbiol. 26:1437-1441. 
[18] National Committee for Clinical Laboratory Standards. 1993. Performance VOL. 41, 1997 antimicrobial susceptibility of Flavobacteria.

[19] National Committee for Clinical Laboratory Standards. 1997.Methods for dilution antimicrobial susceptibility tests for bacteria that grow aerobically. Approved standard M7-A3. National Committee for Clinical Laboratory Standards, Villanova, $\mathrm{Pa}$.

[20] National Committee for Clinical Laboratory Standards. 2002. Reference Method for Broth Dilution Antifungal Susceptibility Testing of Conidium-Forming Filamentous Fungi: Proposed Standard M38-A. NCCLS, Wayne, PA, USA.

[21] National Committee for Clinical Laboratory Standards. 2003. Method for Antifungal Disk Diffusion Susceptibility Testing of Yeast: Proposed Guideline M44-P. NCCLS, Wayne, PA, USA.

[22] Liebowitz, L. D., H. R. Ashbee, E. G. V. Evans, Y. Chong, N. Mallatova, M. Zaidi, D. Gibbs, and Global Antifungal Surveillance Group. 2001.A two year global evaluation of the susceptibility of Candida species to fluconazole by disk diffusion. Diagn. Microbiol. Infect. Dis. 4:27-33.

[23] Matar, M. J., L. Ostrosky-Zeichner, V. L. Paetznick, J. R. Rodriguez, E. Chen, and J. H. Rex .2003. Correlation between E-test, disk diffusion, and microdilution methods for antifungal susceptibility testing of fluconazole and voriconazole. Antimicrob. Agents Chemother. 47:1647-1651.

[24] Kamal A, Khan MN, Srikanth YV, Rajesh SV. 2009. Synthesis and biological evaluation of mercapto triazolobenzothiadiazine linked aminobenzothiazoles as potential anticancer agents. Chem Biol Drug Des. 2009 Jun;73(6):687-93.

[25] Martinez, A., Gil, C., Castro, A., Bruno, A.M, Pérez, C., Prieto, C., Otero, J. 2003.Benzothiadiazine dioxide human cytomegalovirus inhibitors: synthesis and antiviral evaluation of main heterocycle modified derivatives. Antivir Chem Chemother. Mar;14(2):107-14.

[26] Kamal, A., Khan, M.N, Reddy, K.S, Rohin,i K., Sastry, G.N, Sateesh, B. and Sridhar, B. 2007. Synthesis, structure analysis, and antibacterial activity of some novel 10-substituted 2-(4-piperidyl/phenyl)-5,5-dioxo[1,2,4]triazolo[1,5b][1,2,4]benzothiadiazine derivatives. Bioorg Med Chem Lett. 17(19):5400-5.

[27] Nare, B., Prichard, R. K., and Georges, E.1994. Benzimidazoles, potent anti-mitotic drugs: Substrates for the Pglycoprotein transporter in multidrug-resistant cells.Bio Chem Pharmacol., 48, 2215-2222.

[28] Suma,B.V.;Natesh,N.N.;Venkataramana,C.H.;Judy,J. and Madhavan,V. 2012 . Synthesis and antibacterial effect of some new 1,2,3 benzotriazoles derivatives containing pyrazolidinedione moieties. . International Journal of Pharmacy and Pharmaceutical Sciences 4(1) 169-173.

[29] Dvořák, Z.; Starha, P.; Sindelář, Z.and Trávníček, Z. 2012.Evaluation of in vitro cytotoxicity of one-dimensional chain [Fe(salen)(L)](n) complexes against human cancer cell lines. TOXICOLOGY IN VITRO Aprl., Vol. 26 Issue 3 